40. Colloquium der Gesellschaft für Biologische Chemie 6.-8. April 1989 in Mosbach/Baden

\title{
Molecular Mechanisms of Hormone Action
}

Edited by

U. Gehring, E. Helmreich and G. Schultz

With 77 Figures

Springer-Verlag Berlin Heidelberg New York London Paris Tokyo Hong Kong 
Prof. Dr. UlRICH GeHRING

Institut für Biologische Chemie

Universität Heidelberg

Im Neuenheimer Feld 510

6900 Heidelberg, FRG

Prof. Dr. ERnst J.M. HelmReich

Institut für Physiologische Chemie

Universität Würzburg

Koellikerstr. 2

8700 Würzburg, FRG

Prof. Dr. GüNTER SCHULTZ

Institut für Pharmakologie

Freie Universität Berlin

Thielallee 67-73

1000 Berlin 33, FRG

ISBN 3-540-51607-7 Springer-Verlag Berlin Heidelberg New York ISBN 0-387-51607-7 Springer-Verlag New York Berlin Heidelberg

\begin{abstract}
Library of Congress Cataloging-in-Publication Data.
Gesellschaft für Biologische Chemie. Colloqium (40th: 1989: Mosbach, Baden-Württemberg, Germany). Molecular mechanisms of hormone action/40. Colloquium der Gesellschaft für Biologische Chemie, 06.-08. April 1989 in Mosbach/Baden; edited by U. Gehring, E. Helmreich, and G. Schultz. p. cm. 1. Molecular endocrinology-Congresses. 2. Hormones-Physiological effectCongresses. 3. Hormone receptors-Congresses. I. Gehring, Ulrich. II. Helmreich, E. J. M. (Ernst J. M.), 1982- . III. Schultz, G. (Günter), 1936- . IV. Title. [DNLM: 1. Hormones-pharmacologycongresses. WK $102 \mathrm{G} 389 \mathrm{~m}]$ QP187.3.M64G47 1989 615'.36-dc20 DNLM/DLC 89-21860
\end{abstract}

This work is subject to copyright. All rights are reserved, whether the whole or part of the material is concerned, specifically the rights of translation, reprinting, re-use of illustrations, recitation, broadcasting, reproduction on microfilms or in other ways, and storage in data banks. Duplication of this publication or parts thereof is only permitted under the provisions of the German Copyright Law of September 9, 1965, in its version of June 24, 1985, and a copyright fee must always be paid. Violations fall under the prosecution act of the German Copyright Law.

(C) Springer-Verlag Berlin Heidelberg 1989

Printed in Germany

The use of registered names, trademarks, etc. in this publication does not imply, even in the absence of a specific statement, that such names are exempt from the relevant protective laws and regulations and therefore free for general use.

Typesetting: Overseas Typographers, Inc., Makati, Philippines Printing and binding: Brühlsche Universitätsdruckerei, Giessen 2131/3145-543210 


\section{Contents}

Part $1 \ldots \ldots \ldots \ldots$

Mode of Action of Steroid Hormones: A Historical Review

P. Karlson . . . . . . . . . . . . . . . . . . . . . . . . 3

Interaction of Steroid Hormone Receptors with DNA

M. Beato, U. Brüggemeier, G. Chalepakis, B. Gross, B. Piña,

M. Schauer, E.P. Slater, and M. Truss . . . . . . . . . . . 12

Clustered Arrangement and Interaction of Steroid Hormone

Receptors with Other Transcription Factors

R. Renkawitz, R. Schüle, C. Kaltschmidt, C. Baniahmad,

A. Baniahmad, J. Altschmied, Ch. Steiner, and M. Muller . . . . 21

Chromatin Template Remodeling and Steroid Receptor

Transactivation of MMTV

G.L. Hager . . . . . . . . . . . . . . . . . . . . . . . . 29

Hormone-Dependent Transcriptional Activation by Thyroid

Hormone Receptors: Functional Homology with Steroid

Hormone Receptors

S.M. Hollenberg, C.C. Thompson and R.M. Evans . . . . . . . 35

Subunit Structure of the Glucocorticoid Receptor

U. Gehring, M. Rexin, W. Busch, B. Segnitz, and G. Zink . . . 44

Modulation of Glucocorticoid Hormone Action by Oncogenes and Peptide Hormones

B. Groner, W. Höck, W. Doppler, and R. Ball . . . . . . . . . 53

Studies on the Regulation of Glycogen and Lipid Metabolism by Insulin and Growth Factors: The Involvement of Receptor Tyrosine Kinase Activation and Casein Kinase II

T.A.J. Haystead and E.G. Krebs . . . . . . . . . . . . . . . 61

Part 2 .

Genes Coding for G Proteins in Mammalian and Yeast Cells

Y. Kaziro . . . . . . . . . . . . . . . . . . . . . . . . . 75

The ras Oncogene Protein

M.S. Marshall, M.D. Schaber, U.S. Vogel, W.S. Hill, A.S. Ng,

E.M. Scolnick, R.A.F. Dixon, I.S. Sigal, and J.B. Gibbs . . . . 85 
Molecular Mechanisms of G-Protein Activation

K.H. Jacobs, P. Gierschik, G. Hilf, C. Reithmann,

D. Sidiropoulos, and T. Wieland

Interaction of Transducin with Retinal cGMP Phosphodiesterase

Ph. Deterre and M. Chabre . . . . . . . . . . . . . . . . . 100

Phosphonositide Metabolism and Visual Signal Transduction

Z. Selinger and B. Minke . . . . . . . . . . . . . . . . . . 108

Hormonal Regulation of Phospholipases

J.H. Exton

Part 3 . . . . . . . . . . . . . . . . . . . . . . . . . . 125

Regulation of Ion Channels

H. Reuter

The Structure of the Skeletal and Nonskeletal Muscle

Calcium Channel

F. Hofmann, P. Ruth, T. Schneider, J. Felbel, S. Regulla,

M. Biel, W. Nastainczyk, and V. Flockerzi . . . . . . . . . . 132

Involvement of Pertussis Toxin-Sensitive G-Proteins in the

Modulation of Voltage-Dependent $\mathrm{Ca}^{2+}$ Channels by

Extracellular Signals

W. Rosenthal, S. Offermanns, J. Hescheler, K. Spicher,

K.-D. Hinsch, U. Rudolph, and G. Schultz . . . . . . . . . . 139

Multiple Roles of $\mathrm{G}$ Proteins in Coupling of Receptors to

Ionic Channels and Other Effectors

L. Birnbaumer, A. Yatani, J. Codina, A. Van Dongen, R. Graf,

R. Mattera, J. Sanford, and A.M. Brown . . . . . . . . . . . 147

The Guanylate Cyclase Family

D.L. Garbers . . . . . . . . . . . . . . . . . . . . 178

Mechanisms for Hormonal Regulation of the Different Isoforms of Guanylate Cyclase

F. Murad .

Catecholamine Receptors: Structure, Function, and Regulation

M. G. Caron, B.K. Kobilka, M. Bouvier, W.P. Hausdorff,

J.L. Benovic, M. Lohse, S. Cotecchia, J.W. Regan, A. Fargin,

J.R. Raymond, and R.J. Lefkowitz . . . . . . . . . . . . . . 19

Subject Index . . . . . . . . . . . . . . . . . . . . . . . 201 


\section{Contributors}

You will find the addresses at the beginning of the respective contribution

Altschmied, J 21

Ball, R. 53

Baniahmad, A. 21

Baniahmad, C. 21

Beato, M. 12

Benovic, J.L. 195

Biel, M. 132

Birnbaumer, L. 147

Bouvier, M. 195

Brown, A.M. 147

Brüggemeier, U. 12

Busch, W. 44

Caron, M.G. 195

Chabre, M. 100

Chalepakis, G. 12

Codina, J. 147

Cotecchia, S. 195

Deterre, Ph. 100

Dixon, R.A.F. 85

Doppler, W. 53

Evans, R.M. 35

Exton, J.H. 116

Fargin, A. 195

Felbel, J. 132

Flockerzi, V. 132

Garbers, D.L. 178

Gehring, U. 44

Gibbs, J.B. 85

Gierschik, P. 92

Graf, R. 147

Groner, B. 53

Gross, B. 12

Hager, G.L. 29

Hausdorff, W.P. 195

Haystead, T.A.J. 61

Hescheler, J. 139

Hilf, G. 92

Hill, W.S. 85
Hinsch, K.-D. 139

Höck, W. 53

Hofmann, F. 132

Hollenberg, S.M. 35

Jakobs, K.H. 92

Kaltschmidt, C. 21

Karlson, P. 3

Kaziro, Y. 75

Kobilka, B.K. 195

Krebs, E.G. 61

Lefkowitz, R.J. 195

Lohse, M. 195

Marshall, M.S. 85

Mattera, R. 147

Minke, B. 108

Muller, M. 21

Murad, F. 186

Nastainczyk, W. 132

$\mathrm{Ng}$, A.S. 85

Offermanns, S. 139

Pina, B. 12

Raymond, J.R. 195

Regan, J.W. 195

Regulla, S. 132

Reithmann, C. 92

Renkawitz, R. 21

Reuter, H. 126

Rexin, M. 44

Rosenthal, W. 139

Rudolph, U. 139

Ruth, P. 132

Sanford, J. 147

Schaber, M.D. 85

Schauer, M. 12

Schneider, T. 132

Schüle, R. 21

Schultz, G. 139

Scolnick, E.M. 85 
Segnitz, B. 44

Selinger, Z. 108

Sidiropoulos, D. 92

Sigal, I.S. 85

Slater, E.P. 12

Spicher, K. 139

Steiner, Ch. 21
Thompson, C.C. 35

Truss, M. 12

Van Dongen, A. 147

Vogel, U.S. 85

Wieland, T. 92

Yatani, A. 147

Zink, G. 44 


\title{
The Structure of the Skeletal and Nonskeletal Muscle Calcium Channel
}

\author{
F. Hofmann ${ }^{1}$, P. Ruth ${ }^{1}$, T. Schneider ${ }^{1}$, J. Felbel ${ }^{1}$, S. Regulla' ${ }^{1}$, M. Biel ${ }^{1}$, \\ W. NASTAINCZYK ${ }^{1}$, and V. FLOCKERZI ${ }^{1}$
}

\section{Introduction}

A number of fundamental biological processes such as mobility, secretion, and neurotransmission are regulated by a change in the cytosolic calcium concentration. The cytosolic calcium concentration is raised from around 0.1 to $1 \mu \mathrm{M}$ either by a release from cellular stores or by an influx from the extracellular space through voltage-dependent calcium channels. These channels are located in the plasma and transverse tubular membranes of many cells and are classified into at least three types (Nowycky et al. 1985), the T-(tiny or transient), N-(neither T-nor L-, or neuronal), and L- (large or long-lasting) channels. The L-type channels are the target of different organic drugs, the calcium channel blockers, which are used thera peutically in a variety of cardiovascular diseases. L- and N-type channels are not only regulated by the membrane potential or drugs but also by hormones through phosphorylation and/or $\mathrm{G}$ proteins. The electrophysiological properties of the L-type channel have been studied in great detail in cardiac, neuronal, and smooth muscle cells. In contrast, its biochemical and molecular structure has been elucidated up to now only in skeletal muscle.

\section{Structure of the Skeletal Muscle Calcium Channel}

The transversal tubular membranes of the skeletal muscle contain high affinity binding sites for dihydropyridines and phenylalkylamines (Galizzi et al. 1986). The high concentration of the transversal tubular binding sites has facilitated their purification to apparent homogeneity (Curtis and Catterall 1984; Flockerzi et al. 1986a; Takahashi et al. 1987; Leung et al. 1988). The purified channel contains three proteins of $165 \mathrm{kDa}$ $\left(\alpha_{1}\right), 55 \mathrm{kDa}(\beta)$, and $32 \mathrm{kDa}(\gamma)$ which copurify in a constant 1:1:1 ratio (Sieber et al. 1987). A further glycoprotein which contains two disulfide-linked peptides of $135 \mathrm{kDa}$ $\left(\alpha_{2}\right)$ and $28 \mathrm{kDa}(\delta)$ is present in the purified preparation. The relationship of this protein to the other three subunits is unknown.

The oligomeric structure of the channel is unclear at present. Electron microscopy of the purified channel proteins suggests that at least the $\alpha_{1-}, \beta-$, and $\gamma$-subunits are part of a higher ordered structure (Leung et al. 1988). The $\alpha_{1}$-subunit contains the binding sites for calcium channel blockers (Sieber et al. 1987; Striessnig et al. 1986a, 1987;

'Institut für Physiologische Chemie der Universität des Saarlandes, Medizinische Fakultät, D-6650 Homburg-Saar, Fed. Rep. of Germany 
Takahashi et al. 1987), is readily phosphorylated by cAMP-kinase at Ser 687 (Röhrkasten et al. 1988), and has the primary structure of a voltage-dependent ion channel (Tanabe et al. 1987; Ellis et al. 1988). Antibodies specific for the $\alpha_{1^{-}}, \beta$-, and $\gamma$-subunit modulate the calcium channel of cultured cells and the reconstituted skeletal muscle channel supporting an oligomeric structure of the channel and a modulatory role for the $\beta$ - and $\gamma$-subunit (Campbell et al. 1988; Morton et al. 1988; Vilven et al. 1988).

The primary sequence of the $\alpha_{1^{-}}, \alpha_{2^{-}}$, and $\beta$-subunit has been elucidated recently by cloning of the corresponding cDNAs. The structure of the $\gamma$-subunit is not known at present. The $\alpha_{1}$-subunit contains four transmembrane regions which are composed of six transmembrane $\alpha$-helices (Tanabe et al. 1987). The same topology is found in other voltage-dependent ion channels. The deduced amino acid sequence of the $\alpha_{2}$ protein is compatible with that of a peripheral membrane protein, although it contains three transmembrane $\alpha$-helices (Ellis et al. 1988). In agreement with its behavior as glycoprotein several consensus sequences for glycosylation are present in a large extracellular domain of the protein. The $\beta$-subunit contains four hydrophilic, 27 to 42 amino acid long $\alpha$-helices, each of which contains a homologous stretch of eight amino acids (Ruth et al. 1989). The deduced amino acid of this protein is compatible with that of a peripheral membrane protein. The deduced amino acid sequence contains several potential phosphorylation sites. One of these sites, Ser 182, is phosphorylated in vitro by cAMP-kinase. A second and third site may be phosphorylated by cGMP-kinase and protein kinase $\mathrm{C}$ which enzymes modify rapidly the $\beta$-subunit in vitro (Nastainczyk et al. 1987; Jahn et al. 1988).

\section{Binding Characteristics of the Purified Channel}

Only the $165 \mathrm{kDa}\left(\alpha_{1}\right)$ subunit binds the dihydropyridines, phenylalkylamines, and benzothiazepines with high affinity (Flockerzi et al. 1986a; Striessnig et al. 1986b; Sieber et al. 1987). The respective apparent binding constants of the purified receptor are two- to tenfold higher than those of the membrane-bound receptor. The decreased affinity is due mainly to the difficulty in separating rapidly bound and free ligand when the solubilized receptor is used. The binding of dihydropyridines and phenylalkylamines is modulated by calcium. The high affinity binding of PN 200-110, a dihydropyridine, occurs only in the presence of micromolar to millimolar concentrations of calcium. The binding of PN 200-110 is regulated allosterically further by diltiazem and verapamil. In contrast, binding of deva pamil, a verapamil analog, occurs in the absence of calcium if carried out at $4^{\circ} \mathrm{C}$. Micromolar concentrations of calcium inhibit the binding of deva pamil at $4^{\circ} \mathrm{C}$. However, if the binding reaction is carried out at $30^{\circ} \mathrm{C}$, devapamil binds only in the presence of a micromolar concentration of calcium and binding is inhibited by millimolar calcium. Preliminary analysis suggests that 0.1 to $1.0 \mu \mathrm{M}$ calcium decreases the dissociation rate of devapamil at $30^{\circ} \mathrm{C}$. Preincubation of the receptor for less than $20 \mathrm{~min}$ at $30^{\circ} \mathrm{C}$ in the absence of calcium and devapamil prevents binding of devapamil at $4^{\circ} \mathrm{C}$. Apparently, a low concentration of calcium is necessary to stabilize the receptor at $30^{\circ} \mathrm{C}$ in a conformation which allows high affinity binding of devapamil. This apparent temperature dependence is reminiscent of the in vivo situation where the charge transfer of skeletal muscle is 
blocked by calcium channel blockers only at low temperatures and/or after partial depolarization of the plasma membrane (Berwe et al. 1987; Lamb and Walsh 1987; Rios and Brum 1987). Inactivation of the L-type calcium channels, which is induced by an increase in cytosolic calcium, increases the affinity of calcium channel blockers by several orders of magnitude (Bean 1984). This suggests that the conformation of the purified receptor protein complex may fluctuate between two states which are analogous to an active and inactivated channel.

\section{Reconstitution of a Calcium Channel}

The T-tubular localization of the calcium channel blocker binding sites has prevented so far a clear identification of their function. These binding sites may function only as a charge carrier which links membrane depolarization with the intracellular calcium release. Myotubes and single cells contain calcium channels which are similar to L-type channels of cardiac myocytes. T-tubular membranes contain L-type channels if the membrane is reconstituted into a phospholipid bilayer. The open probability of these channels increases after the addition of the calcium channel agonist Bay K 8644, cAMP-kinase and ATP, and the $\alpha$-subunit of the GTP-binding protein of $\mathrm{G}_{\mathrm{s}}$ (Flockerzi et al. 1986b; Talvenheimo et al. 1987; Hymel et al. 1988; Ma and Coronado 1988; Pelzer et al. 1988; Yatani et al. 1988). The channels are blocked by organic and inorganic calcium channel blockers. Similarly, the purified receptor complex reconstitutes to an L-type calcium channel. The opening probability increases after the addition of the channel agonist Bay K 8644, cAMP-kinase, and ATP·Mg. The channel is blocked by organic and inorganic calcium channel blockers and has a single channel conductance of $20 \mathrm{pSi}$ (Flockerzi et al. 1986b; Pelzer et al. 1988). However. the reconstituted proteins support also channels of lower conductance which are not regulated by phosphorylation (Pelzer et al. 1988). The channel-forming protein is the $\alpha_{1}$-subunit since (l) reconstitution of an isolated $\alpha_{1}$-subunit leads to the formation of an L-type calcium channel (Pelzer et al. 1988); (2) injection of the cDNA for the $\alpha_{1}$-subunit into dysgenic muscle cells, which lack the $\alpha_{1}$-subunit, restores E-C coupling and a dihydropyridine-sensitive slow calcium channel in these cells (Tanabe et al. 1988); (3) antisense RNA complementary to the cDNA of the skeletal muscle $\alpha_{1}$-subunit cDNA prevents the expression of cardiac muscle L-type channel in oocytes (Lotan et al. 1989). Thus, it is quite clear that the $\alpha_{1}$-subunit is a calcium channel. This channel has slower opening and closing kinetics than the channel from other tissues, suggesting that the skeletal muscle channel differs from that of other tissues.

\section{Structure of Nonskeletal Muscle L-Type Calcium Channels}

The identity of the L-type calcium channel in other tissues has not been elucidated completely. Photoaffinity labeling of purified protein fractions and membranes suggests that the cardiac muscle receptor for calcium channel blockers is slightly larger than that of skeletal muscle. Apparent molecular weights of 195 versus $165 \mathrm{kDa}$ have been reported (Schneider and Hofmann 1988; Chang and Hosey 1988). A similar molecular weight has been observed for the brain receptor (Striessnig et al. 1988). 
Northern blots carried out with an oligonucleotide probe derived from the cDNA of the skeletal muscle $\alpha_{1}$-subunit show cross-hybridization to an $8.2 \mathrm{~kb}$ mRNA in brain, heart, and smooth muscle and to a $6.3 \mathrm{~kb}$ mRNA in skeletal muscle, suggesting again that the skeletal muscle channel differs from that of other excitable tissues. Monoclonal antibodies against the $\alpha_{1}$-subunit of the rabbit skeletal muscle channel do not specifically label proteins of other tissues. These antibodies detect the $\alpha_{1}$-subunit in the skeletal muscle from human, rabbit, guinea pig, hamster, cow, pig, chick, and frog. In contrast, antibodies directed against the $\alpha_{2}$-proteins of the rabbit skeletal muscle receptor label an identical or similar protein in a wide variety of tissues, including skeletal muscle, heart, brain, and smooth muscle (Schmid et al. 1986; Norman et al. 1987). Similarly, the cDNA of the $\alpha_{2}$-protein hybridizes with the mRNA of other tissues in Northern blots (Ellis et al. 1988). This supports again the notion that an identical $\alpha_{2}$-protein is present in all tissues, whereas the $\alpha_{1}$-subunit differs quite considerably from that of skeletal muscle. So far, it is unclear whether the $\beta$ - and $\gamma$-subunit are part of the calcium channel of other tissues. Preliminary data suggest that mRNA and a protein similar to the $\beta$-subunit of skeletal muscle may be present in brain. It is therefore possible that both subunits are present in other tissues. The proteins associated with the $\mathrm{N}$-type channel are distinct from these proteins. $\mathrm{N}$-type channels bind specifically $\omega$-conotoxin and have a reported molecular weight of above 200 kDa (Abe and Saisu 1987; Barhanin et al. 1988; Marqueze et al. 1988).

\section{In Vivo Regulation and Conclusions}

Calcium channels are regulated in vivo by three mechanisms: The membrane potential, protein kinases, and $G$ proteins. The latter two mechanisms are of interest since they allow hormonal regulation of channel opening and closing. Cyclic AMPdependent protein kinase increases the open probability of the cardiac and some neuronal L-type channels in vivo (Trautwein et al. 1986; Gray and Johnston 1987). The protein phosphorylated in vivo is unknown but the work with the skeletal muscle channel suggests that it may be the $\alpha_{1}$-subunit. The $\alpha$-subunits of $\mathrm{G}_{0}, \mathrm{G}_{\mathrm{i}}$, and $\mathrm{G}_{\mathrm{s}}$ appear to regulate the opening and closing probability of calcium channels in neuronal, neurosecretory, and cardiac cells (Yatani et al. 1987; Rosenthal et al. 1988). The exact mechanism has not been determined in most cases. The opening probability of reconstituted cardiac and skeletal muscle calcium channels increases after addition of the $\alpha$-subunit of $\mathrm{G}_{\mathrm{s}}$. However, it is unclear whether the $\alpha_{1}$-subunit of $\mathrm{G}_{\mathrm{s}}$ directly affects a cardiac calcium channel in vivo, since inhibition of cAMP-kinase blocks the $\beta$-adrenergic stimulation of the cardiac calcium current. However, recently it has been found that the $\beta$-adrenergic receptor of isolated tracheal smooth muscle cells stimulates the calcium current (Felbel et al. 1989). This stimulation was not mimicked by the catalytic subunit of cAMP-kinase but was mimicked by GTP $\gamma$ S. This finding suggests that in these smooth muscle cells the $\alpha$-subunit of $\mathrm{G}_{\mathrm{s}}$ may couple directly to the calcium channel. These results support therefore the hypothesis that L-type calcium channels are regulated by multiple mechanisms in vivo. was supported by grants of the Fonds der chemischen Industrie and Deutsche Forschungsgemeinschaft. 


\section{References}

Abe, T. \& Saisu, H. (1987) Identification of the receptor for $\omega$-conotoxin in brain. J. Biol. Chem. 262:9877-9882

Barhanin, J., Schmid, A. \& Lazdunski, M. (1988) Properties of structure and interaction of the receptor for $\omega$-conotoxin, a polypeptide active on $\mathrm{Ca}^{*}$ - channels. Biochem. Biophys. Res. Commun. 150: $1051-1062$

Bean, B.P. (1984) Nitrendipine block of cardiac calcium channels: high-affinity binding to the inactivated state. Proc. Natl. Acad. Sci. USA 81:6388-6392

Berwe, D., Gottschalk, G. \& Lüttgau, C.H. (1987) Effects of the calcium antagonist gallopamil (D600) upon excitation-contraction coupling in toe muscle fibres of the frog. J. Physiol. 385:693-707

Campbell, K.P., Leung, A.T., Sharp. A.H., Imagawa, T. \& Kahl, S.D. (1988) Ca" channel antibodies: subunit-specific antibodies as probes for structure and function. In: Morad M., Nayler, W.G.. Kazda. S. \& Schramm, M. (eds.) The calcium channel: structure, function and implication. Springer, Berlin Heidelberg New York Tokyo, pp. 586-600

Chang, C.F. \& Hosey, M.M. (1988) Dihydropyridine and phenylalkylamine receptors associated with cardiac and skeletal muscle calcium channels are structurally different. J. Biol. Chem. 263: 18929-18937

Curtis, B.M. \& Catterall, W.A. (1984) Purification of the calcium antagonist receptor of the voltage-sensitive calcium channel from skeletal muscle transverse tubules. Biochemistry 23:2113-2118

Ellis, S.B., Williams, M.E., Ways, N.R., Brenner, R., Sharp. A.H., Leung, A.T., Campbell, K.P., McKenna, E., Koch, W.J., Hui, A., Schwartz, A. \& Harpold, M.M. (1988) Sequence and expression of mRNAs encoding the $\alpha_{1}$ and $\alpha_{2}$, subunits of a DHP-sensitive calcium channel. Science 241:1661-1664

Felbel, J., Welling, A., Peper, K. \& Hofmann, F. (1989) Activation of the $\beta$-adrenergic receptor increases L-type calcium current independent of cAMP and cAMP-kinase in adult tracheal smooth mucle cells. Biol. Chem. Hoppe-Seyler 370:787

Flockerzi, V., Oeken, H.-J. \& Hofmann, F. (1986a) Purification of a functional receptor for calcium channel blockers from rabbit skeletal muscle microsomes. Eur. J. Biochem. 161:217-224

Flockerzi, V., Oeken, H.-J., Hofmann, F., Pelzer, D., Cavaliè, A. \& Trautwein, W. (1986b) The purified dihydropyridine binding site from skeletal muscle T-tubules is a functional calcium channel. Nature (London) 323:66-68

Galizzi, D.-P., Borsotto, M., Barhanin, J., Fosset, M. \& Lazdunski, M. (1986) Characterization and photoaffinity labeling of receptor sites for the $\mathrm{Ca}^{2}{ }^{+}$channel inhibitors d-cis-diltiazem, ( \pm )-bepridil, desmethoxyverapamil, and (+)-PN 200-110 in skeletal muscle transverse tubule membranes. J. Biol. Chem. 261:1393-1397

Gray, R. \& Johnston, D. (1987) Noradrenaline and beta-adrenoceptor agonists increase activity of voltage-dependent calcium channels in hippocampal neurons. Nature (London) 327:620-622

Hymel, L., Striessnig, J., Glossmann, H. \& Schindler, H. (1988) Purified skeletal muscle 1,4-dihydropyridine receptor forms phosphorylation-dependent oligomeric calcium channels in planar bilayers. Proc. Natl. Acad. Sci. USA 85:4290-4294

Jahn, H., Nastainczyk, W., Röhrkasten, A., Schneider, T.\& Hofmann, F. (1988) Site specific phosphorylation of the purified receptor for calcium channel blockers by cAMP-, cGMP-dependent protein kinase, protein kinase $\mathrm{C}$, calmodulin-dependent protein kinase II, and casein kinase II. Eur. J. Biochem. 178:535-542

Lamb, G.D. \& Walsh, T. (1987) Calcium currents, charge movement and dihydropyridine binding in fastand slow-twitch muscle of rat and rabbit. J. Physiol. 393:595-617

Leung, A.T., Imagawa, T., Block, B., Franzini-Armstrong, C. \& Campbell, K.P. (1988) Biochemical and ultrastructural characterization of the 1,4-dihydropyridine receptor from rabbit skeletal muscle. J. Biol. Chem. 263:994-1001

Lotan, I., Goelet, P., Gigi, A.\& Dascal, N. (1989) Specific block of calcium channel expression by a fragment of dihydropyridine receptor cDNA. Science 243:666-669

Ma, J. \& Coronado, R. (1988) Heterogeneity of conductance states in calcium channels of skeletal muscle. Biophys. J. 53:387-395

Marqueze, B., Martin-Moutot, N., Leveque, C. \& Couraud, F. (1988) Characterization of the $\omega$-conotoxin-binding molecule in rat brain synaptosomes and cultured neurons. Mol. Pharmacol. $34: 87-90$ 
Morton, M.E., Caffrey, J.M.. Brown. A.M.\& Froehner, S.C. (1988) Monoclonal antibody to the $\alpha 1$ subunit of the dihydropyridine-binding complex inhibits calcium currents in $\mathrm{BC} 3 \mathrm{HI}$ myocytes. J. Biol. Chem. 263:613-616

Nastainczyk. W., Röhrkasten. A.. Sieber. M.. Rudolph. C.. Schächtele. C.. Marme. D.\& Hofmann. F. (1987) Phosphorylation of the purified receptor for calcium channel blockers by cAMP kinase and protein kinase C. Eur. J. Biochem. 169:137-142

Norman. R.I.. Burgess, A.J., Allen. E. \& Harrison. T.M. (1987) Monoclonal antibodies against the 1.4-dihydropyridine receptor associated with voltage-sensitive $\mathrm{Ca} \cdot$ - channels detect similar polypeptides from a variety of tissues and species. FEBS Lett. 212:127-132

Nowycky, M.C.. Fox. A.P. \& Tsien. R.W. (1985) Three types of neuronal calcium channel with different calcium agonist sensitivity. Nature (London) 316:440-443

Pelzer. D.. Cavalié, A.. Flockerzi, V.. Hofmann, F.\& Trautwein. W. (1988) Reconstitution of solubilized and purified dihydropyridine receptor from skeletal muscle microsomes as two single calcium channel conductances with different functional properties. In: Morad. M.. Nayler. W.G.. Kazda. S.. Schramm. M.(eds.) The calcium channel: structure. function and implication. Springer. Berlin Heidelberg New York Tokyo, pp 217-230

Rios. E. \& Brum, G. (1987). Involvement of dihydropyridine receptors in excitation-contraction coupling in skeletal muscle Nature (London) 235:717-720

Röhrkasten. A.. Meyer, H., Nastainczyk. W., Sieber, M. \& Hofmann. F. (1988) cAMP-dependent protein kinase rapidly phosphorylates Ser 687 of the rabbit skeletal muscle receptor for calcium channel blockers. J. Biol. Chem. 263:15325-15329

Rosenthal. W.. Hescheler, J.. Trautwein. W. and Schultz, G. (1988) Control of voltage-dependent Ca" channels by $G$ protein-coupled receptors. FASEB J. 2:2784-2790

Ruth, P., Röhrkasten, A., Biel, M., Bosse, E., Regulla, S., Meyer, H.E.. Flockerzi, V. \& Hofmann, F. (1989) Primary structure of the $\beta$-subunit of the dhp-sensitive calcium channel from skeletal muscle. Science, in press

Schmid. A.. Barhanin. J.. Coppola, T., Borsotto, M. \& Lazdunski, M. (1986) Immunochemical analysis of subunit structures of 1.4-dihydropyridine receptor associated with voltage-dependent $\mathrm{Ca}^{2} \cdot$ channels in skeletal, cardiac, and smooth muscles. Biochemistry 25:3492-3495

Schneider, T. \& Hofmann, F. (1988) The bovine cardiac receptor for calcium channel blockers is a $195 \mathrm{kDa}$ protein. Eur. J. Biochem. 174:127-135

Sieber, M., Nastainczyk, W.. Zubor. V., Wernet. W. \& Hofmann. F. (1987) The 165-kDa peptide of the purified skeletal muscle dihydropyridine receptor contains the known regulatory sites of the calcium channel. Eur. J. Biochem. 167:117-122

Striessnig, J.. Moosburger, K., Goll, D., Ferry, D.R. \& Glossmann. H. (1986a) Stereoselective photoaffinity labelling of the purified 1,4-dihydropyridine receptor of the voltage-dependent calcium channel. Eur. $\mathbf{J}$. Biochem. 161:603-609

Striessnig, J., Goll, A., Moosburger, K. \& Glossmann, H. (1986b). Purified calcium channels have three allosterically coupled drug receptors. FEBS Lett. 197:204-210

Striessnig, J.. Knaus, H.-G.. Grabner, M.. Moosburger, K.. Seitz, W., Lietz, H. \& Glossman, H. (1987) Photoaffinity labelling of the phenylalkyla mine receptor of the skeletal muscle transverse-tubule calcium channel. FEBS Lett. 212:247-253

Striessnig, J., Knaus, H.-G. \& Glossmann, H. (1988) Photoaffinity-labelling of the calcium-channel-associated 1,4-dihydropyridine and phenylalkylamine receptor in guinea-pig hippocampus. Biochem. J. 253:39-47

Takahashi, M., Seagar, M.J., Jones, J.F., Reber, B.F.X. \& Catterall, W.A. (1987) Subunit structure of dihydropyridine-sensitive calcium channel from skeletal muscle. Proc. Natl. Acad. Sci. USA $84: 5478-5482$

Talvenheimo, J.A., Worley, III J.F. \& Nelson M.T. (1987) Heterogeneity of calcium channels from a purified dihydropyridine receptor preparation. Biophys. J. 52:891-899

Tanabe, T., Takeshima, H., Mikami, A., Flockerzi, V., Takahashi, H., Kangawa, K., Kojima, M., Matsuo, H., Hirose. T. \& Numa. S. (1987) Primary structure of the receptor for calcium channel blockers from skeletal muscle. Nature (London) 328:313-318

Tanabe. T., Beam, K.G., Powell, J.A. \& Numa, S. (1988) Restoration of excitation-contraction coupling and slow calcium current in dysgenic muscle by dihydropyridine receptor complementary DNA. Nature (London) 366:134-139 
Trautwein, W., Kameyama, M., Hescheler, J. \& Hofmann, F. (1986) Cardiac calcium channels and their transmitter modulation. Progr. Zool. 33:163-182

Vilven, J., Leung, A.T., Imagawa, T., Sharp, A.H., Campbell, K.P. \& Coronado, R. (1988) Interaction of calcium channels of skeletal muscle with monoclonal antibodies specific for its dihydropyridine receptor. Biophys. J. 53:556a

Yatani, A., Codina, J., Imoto, Y., Reeves, J.P., Birnbaumer, L. \& Brown. A.M. (1987) A G-protein directly regulates mammalian cardiac calcium channels. Science 238:1288-1292

Yatani, A., Imoto, Y.. Codina, J., Hamilton, S.L., Brown, A.M. \& Birnbaumer. L. (1988). The stimulatory G-protein of adenylyl cyclase, Gs, also stimulates dihydropyridine-sensitive $\mathrm{Ca}^{2} \cdot{ }^{2}$ channels. J. Biol. Chem. 263:9887-9895 